P03

Burial Dolomitization, Late Leaching and Thermochemical Sulphatereduction Diagenesis in Arab C and D Reservoirs (Kingdom of Saudi Arabia): Impact on Reservoir Properties

C. Taberner* (Shell Global Solutions NL), G. Sosa (University of Goettingen), A. van den Kerkhof (University of Goettingen), J. Sneep (South Rub Al-Khali Company Limited) \& A. Bell (Shell Global Solutions NL) 


\title{
15309 Burial dolomitization, late leaching and thermochemical sulphate-reduction diagenesis in Arab C and D reservoirs (Kingdom of Saudi Arabia): Impact on reservoir properties
}

\author{
Conxita Taberner (Shell Global Solutions <conxita.taberner@shell.com>), Graciela Sosa (University of \\ Goettingen, Germany), Alfons van den Kerkhof (University of Goettingen, Germany), \\ Rik Sneep (South Rub’ Al-Khali Company) and Andy Bell (Shell Global Solutions)
}

Diverse diagenetic processes have been proposed to explain the reservoir properties of the Arab C and D reservoirs in the Middle East: from early diagenesis (e.g. early cementation, dissolution and / or dolomitization) to burial and late burial diagenesis (e.g. compaction, cementation, burial dolomitization, leaching, hydrothermal/fault-related dolomitization). This contribution examines the Arab C and D reservoirs from an onshore field in Saudi Arabia with specific focus on: (1) late diagenetic evolution; (2) timing of burial diagenesis with respect to charge; and (3) their impact on reservoir rock and fluid properties.

The Arab D Reservoir in the studied field is mainly formed by ooid grainstones corresponding to a carbonate shoal environment. The reservoir properties of the Arab D are mostly controlled by the interplay of: (1) porosity-destructing diagenetic processes (early and burial cementation, compaction and late burial cementation associated to themochemical sulphate reduction); (2) porosity preservation (interparticle porosity and intraparticle microporosity); and/or (3) the effect of porosity-enhancing diagenetic processes (dissolution of calcitic components and cements and/or dissolution of late anhydrite cements during late burial).

The Arab C Reservoirs correspond to the open-marine facies of salinity increase parasequences. The most prominent diagenetic process controlling Arab C Reservoir properties was burial dolomitization of: (1) skeletal-intraclast grainstones and rudstones; and (2) pervasively bioturbated peloidal grainstones. Lateral continuity of the Arab C Reservoir units mimics the original depositional architecture; however leaching associated to dolomitization and/or leaching post-dating dolomitization, mostly improved rock properties in a pattern that appears to be strongly controlled by the early depositional and diagenetic products.

The products of thermochemical sulphate reduction have been observed in the Arab $C$ and in Arab $\mathrm{D}$ reservoirs. Although volumetrically not very relevant, the impact in rock properties was locally significant, as newly formed cements have been observed to affect rock properties negatively (e.g. precipitation of dolomite, calcite and late anhydrite cements), or positively (e.g. dissolution of calcite and dolomite with localized increase of porosity and more general increase of permeability due to pore throat enlargement).

Geochemical information obtained in late cements include $\delta^{13} \mathrm{C}$ and $\delta^{18} \mathrm{O}$ of carbonates, $\delta^{34} \mathrm{~S}$ and $\delta^{18} \mathrm{O}$ of sulphates, ${ }^{87} \mathrm{Sr} /{ }^{86} \mathrm{Sr}$ of carbonates, sulphates and fluorite and fluid-inclusion microthermometry and gas-composition analyses. This information allows a refined interpretation of the late diagenesis processes and understanding of their impact on the reservoir properties (increase, decrease and/or redistribution of porosity). The fluid evolution of the Arab C and D reservoirs during late diagenesis until present-day can be inferred from fluid inclusion information.

The integration of diagenetic and geochemical signatures with charge evaluation and structural information suggest the inflow of deep-seated fluids, coeval to charge, in both the Arab C and Arab D reservoirs. The temperature increase, driven by the inflow of deep-seated fluids, could have triggered thermochemical sulphate reduction in the reservoirs. In this scenario, lateral reservoir heterogeneity is expected to be associated to the location of deep-seated faults.

\section{Acknowledgements}

SRAK and Saudi Aramco are acknowledged for granting permission to present these results. 